DOI: https://doi.org/10.47405/mjssh.v6i1.602

\begin{tabular}{|c|c|}
\hline 4 & Malaysian Journal of Social Sciences and Humanities (MJSSH) \\
\hline Malaysian Journal of & Volume 6, Issue 1, January 2021 \\
\hline (MJ-SSH) & e-ISSN : 2504-8562 \\
\hline & $\begin{array}{l}\text { Journal home page: } \\
\text { www.msocialsciences.com }\end{array}$ \\
\hline
\end{tabular}

\title{
The Impact of El Niño-Southern Oscillation (ENSO) on Temperature: A Case Study in Kuching, Sarawak
}

\author{
Ricky Anak Kemarau1 ${ }^{1}$, Oliver Valentine Eboy ${ }^{1}$ \\ ${ }^{1}$ Faculty of Social Science and Humanities, Universiti Malaysia Sabah (UMS) \\ Correspondence: Ricky Anak Kemarau (ricky.geo2005@gmail.com)
}

\begin{abstract}
The El Niño-Southern Oscillation (ENSO) event is a climate event that has an impact on the world climate. The effects of ENSO are often associated with prolonged droughts and floods since 1980 following global climate change. In addition to causing flooding and drought. Indirectly, the occurrence of ENSO causes health problems, environmental destruction, affecting economic activities such as agriculture and fisheries. Many studies on ENSO have been conducted. However, there is still a lack of research on the effect of ENSO on temperature in local knowledge areas, especially urban areas because the urban environment especially building materials that can absorb and release heat. In addition, previous studies have focused on large-scale areas. Beside that there still gap to understand and increase knowledge about the effect of ENSO on local temperatures, especially in urban areas. This study uses meteorological data and Oceanic Nino Index (ONI) from 1988 to 2019. This study found that the occurrence of ENSO has an effect on the value of daily temperature but differs based on the value of the ONI index. In addition, this study uses linear regression in predicting the effect of ENSO on temperature. The results of this study are useful to those responsible for understanding the impact of ENSO on temperature in urban areas to provide infrastructure in reducing the impact of ENSO as well as adjustment measures during the occurrence of ENSO.
\end{abstract}

Keywords: ENSO, meteorology data, ONI, model prediction, urban areas

\section{Introduction}

In short, ENSO is a climate phenomenon that occurs in areas in the Pacific Ocean but has a wide impact on weather and climate around the world. The occurrence of ENSO is often associated with drought and flood disasters (Kovats et al., 2003). The occurrence of ENSO consists of three phases of ENSO known as El Niño (warm tropical Pacific SST), La Niña (cold tropical SST) and Neutral (not El Niño or La Niña) (Chen, 2002). Every incident has clearly different characters (Trenberth and Stepaniak 2001).

In addition, each episode differs in relative strength, maturity, beginning of season and end, duration and level of SUHU temperature anomaly in the tropical Pacific (Lyon \& Barnston, 2005). El Niño and La Niña show extreme climate change and weather. For example, During El Niño, global temperatures rise by $0 \cdot 5^{\circ} \mathrm{C}$ on average (Kovats \& Bouma, 2003). Yet differences in precipitation are heterogonous (Ropelewski \& Halpert, 1996). In general, the El Niño (La Niña) phase is associated with warming temperatures in the tropical Pacific and the Indian Ocean that reduce rainfall in the western (eastern) Pacific region (Allan et al., 2000). 
Trenberth and Stepaniak (2001) report many severe and prolonged ENSO incidents have been recorded such as the two most extreme El Niños (1982-1983, 1997-1998, 2015-2016) and La Niña (1988-1989, 1973-1974) (Fang and Xie, 2019). The strongest and recurring effects of ENSO have been since the 1980s, a pattern that may be related to global warming (Ashok and Yamagata, 2009). The occurrence of ENSO also affects every aspect of human society: epidemics (Chen et al., 2005), natural disasters (Hu et al., 2012), energy demand (Paek et al., 2017), scarcity and excess water resources (Barton and Ram 1' rez 2004), forest fires (Rosenzweig, C. and D. Hillel 2008).), volatile fishing catches (Villoria, 2015), low agricultural yields (Luo et al. 2014), economic well-being (Risbey et al., 2014), and many others (Hachigonta et al., 2006; Gilman et al., 2014). The World Meteorological Organization (WMO) takes seriously the impact of ENSO on climate and weather. This causes them to constantly update meteorological and oceanographic data on a quarterly basis to monitor and predict ENSO episodes.

The following are studies that have conducted studies on the correlation between ENSO and temperature (Mou et al., 2020; Tavakol et al., 2020; Rane et al., 2019; Fang et al., 2016). In the Malaysian context, the occurrence of ENSO affects climate change in Malaysia (Tangang et al., 2012). but there is still little research to understand the effect of ENSO on temperature (Mou et al., 2020) in urban area. In addition, a study by Mou et al. (2020), Wall et al. (2020) and Rene et al. (2019) who studied the effects of ENSO on climatological and meteorological data. Mou et al. (2020), Tangang et al. (2019) and Dinding et al. (2020) make a study for the whole of Malaysia. Their study found that ENSO affects temperature and total rainfall. In addition, Mou et al. (2020) concluded that the increase in temperature in urban areas due to the urbanization process. Their decision contradicts Siti et al., (2018) which states several climates and monsoons needed to be considered Indian Ocean Dipole (IOD) and Madden-Julian Oscillation (MJO) affect the city's temperature to be neutral. Due to the conflicting results between Mou et al. (2020) and Siti et al. (2018) increased motivation the need to study the effect of ENSO on plants and temperature.

In addition, Renganathan and Rohinton (2018) state that future studies should focus on identifying the nature of the relationship between ENSO and urban climate in tropical regions. Currently, studies on the influence of ENSO on urban climate are still under-researched by researchers. As we all know, one study has shown the influence of climate change and ENSO on surface temperature. This raises the question Does the ENSO representing the ONI index and the magnitude of the ENSO affect the meteorological data i.e. surface temperature? Finally, identify the relationship between ONI index and meteorological data?

\section{Study Area}

Temperatures in the study area are hot throughout the year, with average daily temperatures ranging from 23 degrees Celsius in the early morning to 32 degrees Celsius during the day (Zulfaqar et al., 2017; Kottek et al., 2006). The climate in Kuching is influenced by MJO, ENSO, IOD (Hua et al., 2013) and Monsoon season (Dindang et al., 2013; Yik et al., 2015).

In recent years, ENSO phenomena, climate change, and several incidents of heavy rainfall have been reported in Borneo Malaysia including in the study area, namely Kuching (Zulfaqar et al., 2017). In 2015, the floods left many low-lying areas in Kuching, Sarawak (Zulfaqar et al., 2017). On the other hand, 2009 was also recognized as the last year for Sarawak when two major rainfall events caused severe floods covering the whole of Sarawak including Kuching (Hamdan et al., 2010). This phenomenon has raised concerns to encourage more research on meteorological data flow analysis to examine whether these changes are statistically significant or significant (Zulfaqar et al., 2017).

\section{Methodology}

A total of 385 temperatures from the Malaysian Meteorological Department (MMD) and Oceanic Nino Index (ONI) data from 1988 to 2019 were used in this study. This study uses correlation, 
DOI: https://doi.org/10.47405/mjssh.v6i1.602

regression and compare mean with One Way ANOVA (Analysis of variance) in the analysis tool IBM (International Business Machines Corporation), Statistics for Social Science SPSS. According to Douglas et al., (2012), the linear regression model is shown as follows:

$\mathrm{Y}=\mathrm{a}+\mathrm{bX}+\mathrm{ei}$

where $\mathrm{Y}$ is the dependent variable (Temperature from MMD); $\mathrm{X}$ is an independent variable (i.e. ONI; $\mathrm{a}, \mathrm{b}$ is an indefinite parameter where each $\mathrm{a}$ is a regression line bypass, and $\mathrm{b}$ is a slope of the regression line; and ei is a random error.

\section{Average Daily Temperature, Maximum Temperature (Max), and Minimum Temperature (Min)}

Daily average temperature data were collected from MMD. Data were collected at Kuching Airport station with latitude 01 degrees 29 'North and longitude 110 degrees 20' East and high above M.S.L 21.7 meters. Data in degrees Celsius. Data used from 1988 to 2019. Monthly mean temperature is calculated from daily temperature, maximum value for a month, and minimum value for a month as shown in table 1 mentioned below.

\section{Oceanic Nino Index (ONI)}

The Oceanic Nino Index (ONI) is commonly used to identify events of El Niño (warm) and La Niña (cold) (Huang et al., 2016). The ONI index shows the development and intensity of El Niño or La Niña events in the Pacific Ocean. ONI is a three-month Sea Temperature (SST) anomaly in Niño region $3.45^{\circ} \mathrm{N}-5^{\circ} \mathrm{S}, 120^{\circ}-170^{\circ} \mathrm{W}$ ). The occurrence of El Niño is defined when the average value of three months at or above $+0.5^{\circ} \mathrm{C}$ anomaly, while the event of La Niña is defined as or under climate Anomaly (NOAA, 2018) $-0.5^{\circ} \mathrm{C}$ Forecast Center, 2019. ENSO value grade is classified to 5 namely Weak (with anomalies 0.5 to 0.9 SST), Medium (1.0 to 1.4), Strong (1.5 to 1.9), and Very Strong $(\geq 2.0)$ for El Niño events and vice versa for La Niño events.

\section{Result}

\section{ONI Value Patterns from 1988 to 2019}

Graph 1 shows the pattern of Oceanic Nino Index values from 1988 to 2019. Oceanic Niño Index $(\mathrm{ONI})$ is measured for ENSO influence values.

Graph 1: ONI value pattens from 1988 until 2019

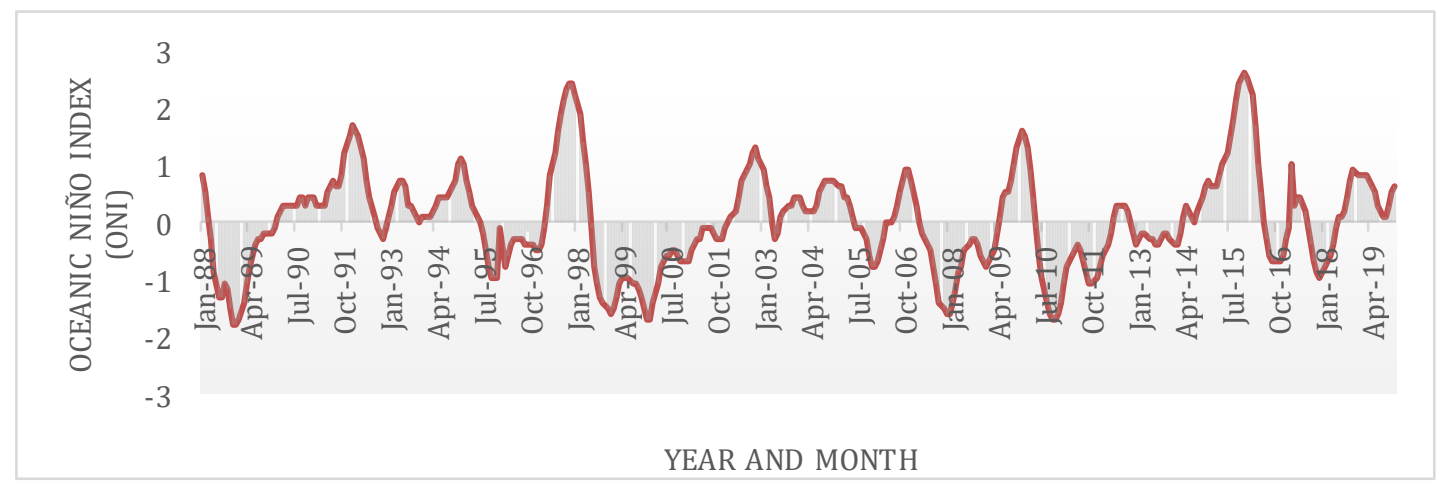

El Niño which represents the ONI value starts from positive 0.5 and above and for La Niña its value starts from negative 0.5 and below. Data obtained from the NOAA website (https://www.noaa.gov/, 2020). For example, as shown in graph 4.1, the year of El Nino in July 1991 to September 1992, May 1997 to July 1998 and November 2014 to January 2016. For La Nina is January 1988 to March 1989, 
July 1998 to September 1999, November 2007, and March 2010 to May 2011. This is the same as stated by Suhaila et al. (2018), Tang et al. (2019) and Mou et al. (2020).

\section{Temperature and ONI Value Patterns from 1988 to 2019}

Graph 2 shows the value of ONI and meteorological MMD for the month from 1988 to 2019. According to graph 2 above shows that there is a positive relationship between ONI and monthly temperature. From May 1988 to May 1989 showed that the ONI value -1 to -1.8 equals 24.8 to $24^{\circ} \mathrm{C}$. The negative value of the ONI represented la Nina in the year included from June 1998, 2007, and 2010. In contrast, in 1997 from June 1997 to April 1998 showed ONI values at 0.8 to 2.4 in November 1997 and December 1997. The values have increased the temperature in the name of the temperature value is 26.4 to $27.9^{\circ} \mathrm{C}$. This phenomenon is the same from the end of 2015 to March 2016. El Nino can also must have occurred in 1991,1 997 to 1998 and 2015 to 2016 (Tang et al., 2019, Tan et al., 2019).

Graph 2: Temperature and ONI value patterns from 1988 to 2019

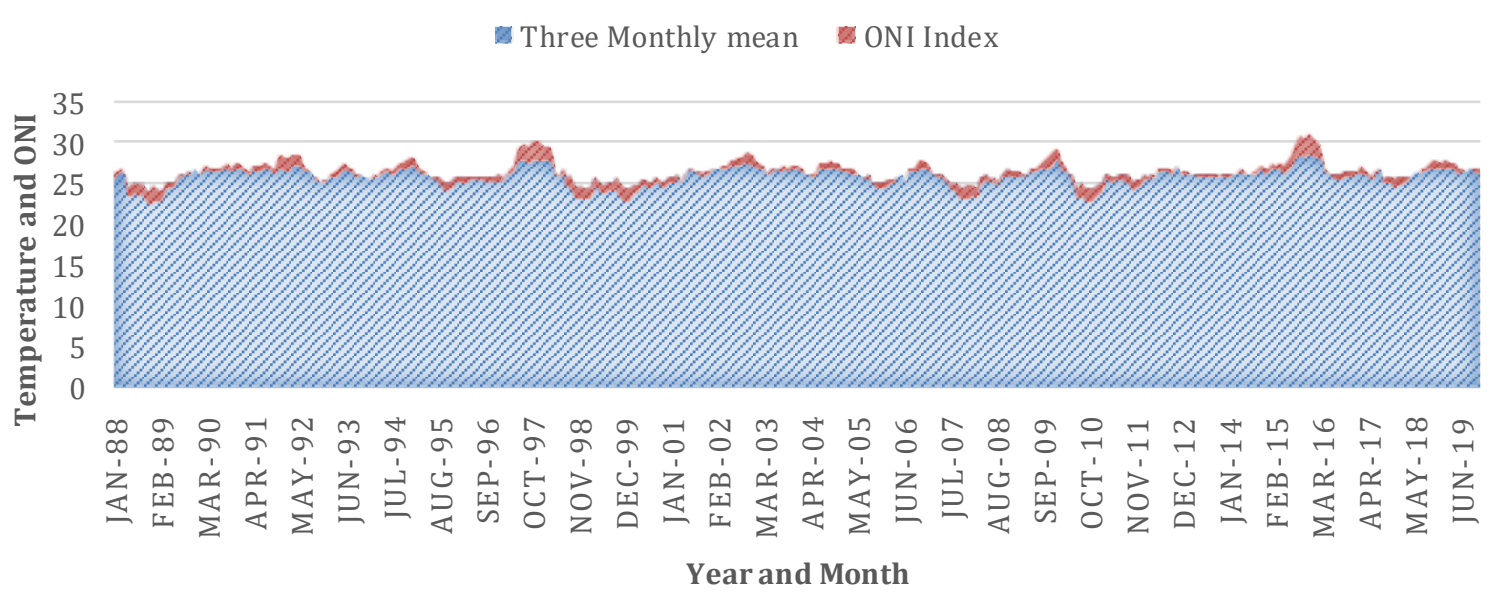

\section{The Correlation Between Temperature and ONI}

Graph 3 shows the direct correlation between ONI and meteorological temperature for three months based on ONI monthly formula. This correlation involves 385 temperatures from MMD from 1988 to 2019. The results show a strong positive correlation between the two variables namely ONI which represents ENSO with the temperature from MMD. with a value of $0.75 \mathrm{R}$.

Graph 3: Correlation between temperature and ONI

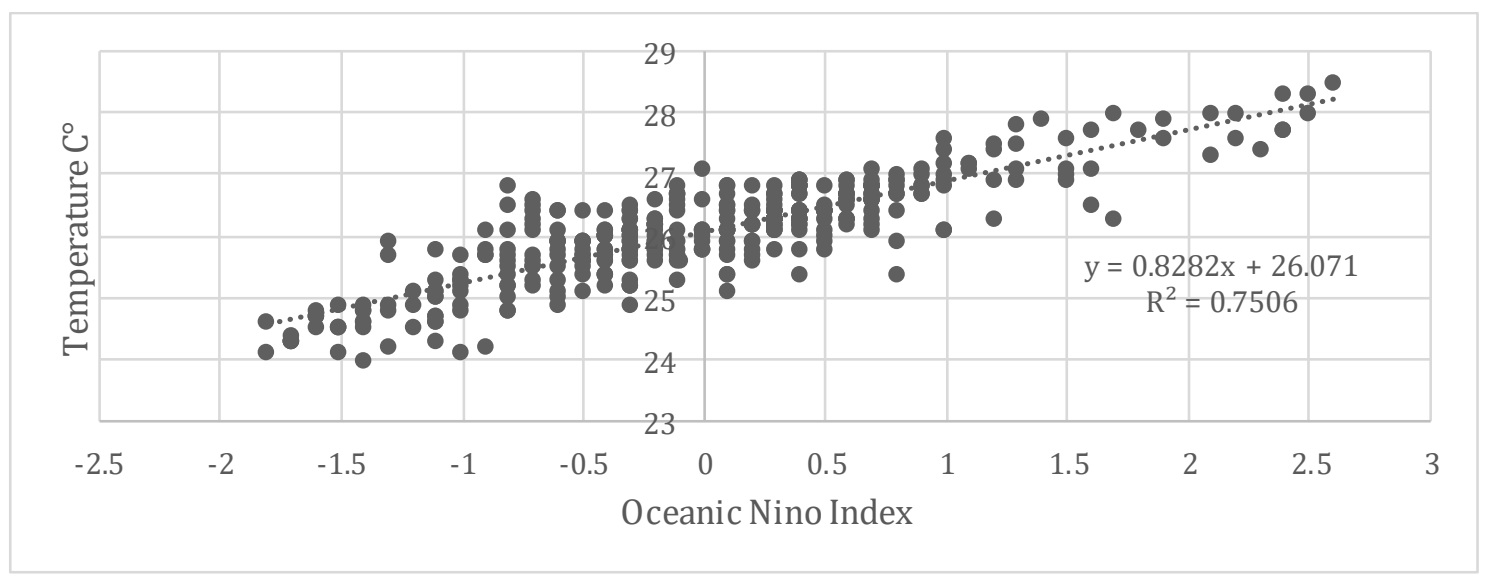


DOI: https://doi.org/10.47405/mjssh.v6i1.602

\section{Regression Model to Predict the Effect of ENSO on Meteorological Temperatures}

Table 1 shows the linear regression model in predicting the effect of ENSO on meteorological temperatures. This table gives the values of $\mathrm{R}$ and $\mathrm{R}^{2}$. The value of $\mathrm{R}$ represents a high correlation of 0.855 which is the effect of ONI on Meteorological temperature. The value of $\mathrm{R}^{2}$ (column " $\mathrm{R}^{2}$ ) of 0.73 indicates how much variation in the dependent variable, ONI, can be explained by the independent variable, ONI. In this case, $73.1 \%$ can be explained by ONI.

Table 1: Regression model

\begin{tabular}{lllll}
\hline Model & $\mathbf{R}$ & $\mathbf{R}^{\mathbf{2}}$ & ${\text { Adjusted } \mathbf{R}^{\mathbf{2}}}$ & Standard error for the estimation \\
\hline 1 & 0.855 & 0.731 & 0.730 & 0.3901 \\
\hline
\end{tabular}

Table 2 next is the Variance Analysis (ANOVA) table, which reports how well the regression equations correspond to the data (i.e., predicting dependent variables) and are shown below. This table shows that the regression model predicts the dependent variable well. This shows the statistical significance of the regression model carried out. Here, $\mathrm{p}<0.0005$, which is less than 0.05 , and shows that, overall, the regression model statistically predicts the outcome variable (i.e., it is appropriate for the data).

Table 2: ANOVA

\begin{tabular}{llllll}
\hline Model & Sum of squares & Df & Mean Square & F & Sig \\
\hline Regression & 97.209 & 1 & 97.209 & 638.555 & 0.000 \\
Residual & 35.77 & 235 & 0.152 & & \\
Total & 132.984 & 236 & & & \\
\hline
\end{tabular}

Table 3 next is the ANOVA table, which reports how well the regression equation corresponds to the data (i.e., predicting the dependent variable) and is shown below. The statistical significance of each independent variable tests whether the non-standard (or standard) coefficient is equal to 0 (zero) in the population that releases each of these coefficients, $\mathrm{H}_{-} 0=\mathrm{B}=0$ versus Ha: $\mathrm{B} \neq 0$ is carried out. If $\mathrm{P}$ $<0.05$, the coefficient is statistically significant to 0 (zero). In this case, the test shows an ONI index of $\mathrm{P}$ value 0.000 . That explains the ONI variable is significant for this model.

Table 3: ANOVA

\begin{tabular}{llllll}
\hline Model & $\begin{array}{l}\text { Unstandardized } \\
\text { coefficients }\end{array}$ & $\begin{array}{l}\text { Standardized } \\
\text { coefficients }\end{array}$ & $\begin{array}{l}\text { Standard } \\
\text { coefficients }\end{array}$ & T & Sig \\
\cline { 2 - 4 } & B & Std. Error & Beta & & \\
\hline (Constant) & 26.148 & 0.25 & & 1031.397 & 0.000 \\
Oni Index & 0.817 & 0.032 & 0.855 & 27.25 & 0.000 \\
\hline
\end{tabular}

\section{Discussion}

Graph 4 shows a direct correlation between ONI and soil meteorological temperature for three months as. This correlation involves 385 monthly meteorological data, namely temperature and ONI from 1988 to 2019. The average three-month meteorological temperature should be compiled based on the three-month ONI average format. The results show a strong positive correlation between the two variables namely ONI which represents ONI meteorological temperature with a value of $0.75 \mathrm{R}^{2}$. This means that ONI affects the temperature value of meteorological data. For example, the temperature value will increase if the ONI value increases and the meteorological temperature value will decrease if the ONI value decreases. This can be explained that if the value of ONI exceeds 1 carries the meaning of El Nino and if the value exceeds the negative it is La Nina. The associated El Nino causes hot temperatures, droughts and droughts will cause meteorological temperatures higher than usual. 
DOI: https://doi.org/10.47405/mjssh.v6i1.602

Graph 4: Correlation between temperature and ONI

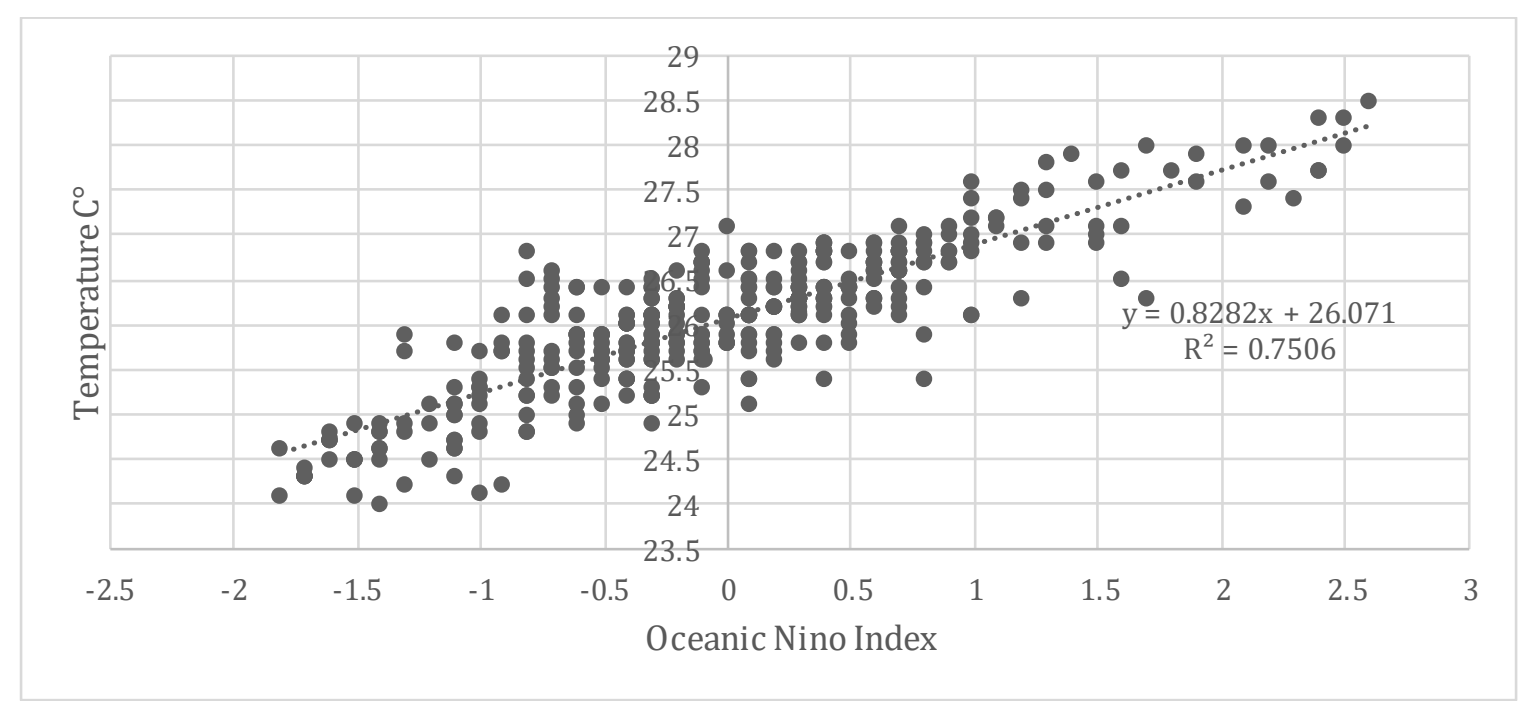

This is due to the increased humidity and rainfall associated with the La Niña period usually reducing the daytime temperature (Drosdowsky, 2014). On the other hand, during El Niño events, decreased humidity and rainfall means that temperatures during the day are usually hotter than usual, resulting in lower rainfall than usual by increasing evaporation (Drosdowsky, 2014). Global temperatures are also affected by La Niña and El Niño events due to heat exchange between the atmosphere and the oceans (Turkington et al., 2018; Australian Meteorological Department, 2020; Malaysian Meteorological Department, 2019).

In addition, Freychet et al. (2018) also found that the highest meteorological temperature values were recorded during the peak of El Nino in 2014 i.e. during the day compared to during the ONI neutral event. Meteorological temperatures were also recorded highest during El Nino peaks at night compared to neutral ONI night temperatures. This is due to the fact that building materials that absorb heat during the day will release heat at night (Freychet et al., 2018). Their study also found the highest meteorological temperature in the interior of China compared to the coast of China. ONI i.e. El Nino causes an increase in temperature from 0.5 degrees to 1 degree Celsius. This is due to the factor of watery areas capable of lowering the temperature (Ricky \& Oliver, 2020, Naeen et al., 2018). Lijie et al. (2018) confirmed that El Nino has caused a temperature rise in Indochina of 0.53 degrees Celsius to 0.60 degrees Celsius at the peak of El Nino. Their study also found that this El Nino incident also weakened the eastern monsoon winds. This statement is also confirmed by Luo and Lau (2018). The occurrence of La Nina and El Nino has the opposite effect on the temperature in Indochina. The study of Lijie et al. (2018) also states that the occurrence of El Nino also causes heat waves to Indochina. This means that the temperature on the surface is higher than normal. This is due to the lack of rainfall in Indochina during El Nino compared to La Nina. The results of this study are similar to the findings of studies such as Lijie et al. (2018) and Lou and Lau (2018).

\section{Regression Prediction Model}

To understand the risks and improve the ability to predict unusual weather various statistics are used in identifying the ONI relationship with rainfall and temperature (Grotjahn et al., 2016; Kenyon \& Hegerl, 2008; Mishra \& Singh, 2011). Linear regression can provide an estimate the response of climate variables on a large-scale including ONI (Min et al., 2013). Table 5 shows the regression prediction model.

Based on table 5 which shows the results of single regression in predicting the effect of ONI on six dependent parameters shows a clear effect on dependent parameters. The highest $\mathrm{R}^{2}$ value is the average monthly temperature from MMD which is 0.730 . The following model explains the effect of ONI on non-dependent parameters. As an example, for the average monthly temperature from MMD 
which is the forecast formula as follows. For example, if the ONI value is 1 then the monthly temperature value of MMD is 26.965 degrees Celsius.

$\mathrm{Y}$ which is the monthly temperature of $\mathrm{JMM}=0.817 *(\mathrm{ONI}$ value $)+26.148$

$26.96=0.817 \mathrm{X} 1+26.14$

Table 5: Regression Prediction Model

\begin{tabular}{llll}
\hline Dependent Parameter $(\mathbf{Y})$ & $\begin{array}{l}\text { Model Predict Impact ONI } \\
(\mathbf{X})\end{array}$ & $\mathbf{R}^{\mathbf{2}}$ & $\begin{array}{l}\text { P- Regression } \\
\text { Coefficient Value }\end{array}$ \\
\hline Temperature from MMD & $\mathrm{Y}=0.817 *(\mathrm{X})+26.148$ & 0.730 & 0.000 \\
\hline
\end{tabular}

\section{Conclusion}

This study successfully achieved the objective of the study which is to study the effect of ENSO on temperature. ENSO incidents represented by ONI. An ONI value with a negative value of 0.5 below it means the occurrence of La Nina and if a positive value of 0.5 above it indicates an El Nino event. ONI values and temperatures are related to positive correlations. This means that if the ONI value increases then the temperature value also increases. This can be seen in the El Nino incidents in 1997 and 1998, 2015 and 2016 where the ONI value increased and caused the temperature value to increase. This study also found that the influence of environmental climate such as IOD, MJO and monsoon cannot affect ENSO to temperature, especially at the time of El Nino maturity. This study also successfully predicted the effect of ENSO on temperature through linear regression statistical methods. The results of this study hope guide line and knowledge that before getting less attention from other researchers that is to identify the effect of ENSO on local temperatures, especially urban areas. The results of this study are useful to those responsible as in urban planning in planning measures in reducing the impact of ENSO on the urban population. The degree of urban heat is higher than other areas during the El Nino incident due to the effects of the urban heat island. Researchers suggest future studies to study the effect of ENSO on temperature, rainfall and humidity.

\section{Acknowledgement}

Thanks to Malaysia Meteorology Department for Daily temperature data.

\section{References}

Allan, R. J. (2000). ENSO and Climatic Variability in The Past 150 Years. ENSO: Multiscale Variability and Global and Regional Impacts: 3-55.

Abul Quasem Al-Amina \& Gazi Mahabubul Alam, (2016). The Impact of El-Niño On AgroEconomics in Malaysia And The Surrounding Regions: An Analysis Of The Events From 199798. Asian J. Earth Sci., 9, 1-8.

Ashok K, Y. T. (2009). The El Niño With A Difference. Nature, 461, 481-484

Barton, S. B. \& J. A. Ram I' Rez (2004). Effects Of El Niño Southern Oscillation and Pacific Interdecadal Oscillation on Water Supply in The Columbia River Basin. Journal of Water Resources Planning and Management, 130(4), 281-289.

Boyin H, L., Zeng-Zhen H, \& Huai-Min Z. (2016). Ranking the Strongest ENSO Events While Incorporating SST Uncertainty. Geophysical Research Letter. Research Letter. 2016. American Geophysical Union.

Chen, C.-C., Et Al. (2002). Agricultural Value of ENSO Information Under Alternative Phase Definition. Climatic Change, 54(3): 305-325.

Chen, D. K., Zebiak, S. E., Busalacchi, A. J., \& Cane, M. A. (1995). An Improved Procedure For El Niño Forecasting: Implications for Predictability. Science, 269,1699-1702 
Douglas C. Montgomery, Elizabeth A. Peck, G. Geoffrey Vining (2012) Introduction To Linear Regression Analysis, 5th Edition.

Drosdowsky, W., Wheeler MC. (2014). Predicting the Onset of The North Australian Wet Season with The POAMA Dynamical Prediction System. Wea. Forecasting, 29, 150-161.

Fang, X., Xie, R. (2020). A Brief Review of ENSO Theories and Prediction. Sci. China Earth Sci. 63, 476-491 (2020). Https://Doi.Org/10.1007/S11430-019-9539-0

Freychet, N., S. Sparrow, S. F. B. Tett, M. J. Mineter, G. C. Hegerl, And D. C. H. Wallom (2018). Impacts of Anthropogenic Forcings And El Nino On Chinese Extreme Temperatures. Adv. Atmos. Sci., 35(8), 994-1002, Https://Doi.Org/10.1007/ S00376-018-7258-8.

Grimm, A. M., Et Al. (1998). Precipitation Anomalies in Southern Brazil Associated With El Niño And La Niña Events. Journal of Climate 11(11), 2863-2880.

Garfinkel, C.I.; Butler, A.H. (2018).Reviews Of Geophysics The Teleconnection Of El Niño Southern Oscillation To Thestratosphere. Rev. Geophys. 2018, 57, 547, Doi:10.1029/2018RG000596

Hachigonta, S., \& C. Reason (2006). Interannual Variability in Dry and Wet Spell Characteristics Over Zambia. Climate Research 32(1), 49.

Hu Z Z, Kumar A, Jha B, Wang W, Huang B, Huang B. (2012). An Analysis of Warm Pool And Cold Tongue El Niños: Air-Sea Coupling Processes, Global Influences, And Recent Trends. Clim Dyn, 38, 2017-2035

Kovats, R. S., Bouma (2003). E1 Niño And Health. The Lancet 362(9394), 1481-1489.

Korecha, D. \& A. G. Barnston (2007). Predictability of June-September Rainfall In Ethiopia. Monthly Weather Review, 135(2): 628-650.

Kottek, M., J. Grieser, C. Beck, B. Rudolf, And F. Rubel, (2006): World Map of The Köppen-Geiger Climate Classification Updated. Meteorol. Z., 15, 259-263, Doi:10.1127/0941-2948/2006/013

Luo, J.-J. (2008). Extended ENSO Predictions Using A Fully Coupled Ocean-Atmosphere Model. Journal of Climate, 21(1), 84-93.

Luo, Q. (2014). Temperature Thresholds and Crop Production: A Review. Climatic Change, 109(3-4): 583-598.

Luo, M. \& Lau, N.-C. (2018) Amplifying Effect of ENSO On Heat Waves In China. Climate Dynamics. Https://Doi.Org/10.1007/S00382-018-4322-0.

Luo, M. \& Lau, N.-C. (2018) Synoptic Characteristics, Atmospheric Controls, And Long-Term Changes Of Heat Waves Over The Indochina Peninsula. Climate Dynamics. Https://Doi.Org/10.1007/S00382-017-4038-6.

MMD (Malaysia Meteorological Department) 2020. Summary of Climate. Available at Http://Www.Met.Gov.My/Iklim/Laporanringkasan/Maklumatiklim (Accessed On 19 September 2020).

Mohamed E. H. (2016). Time Series Trends of Land Surface Temperatures In Egypt: A Signal For Global Warming Environ Earth Sci. 75:1218 DOI 10.1007/S12665-016-6024-4

NOAA 2020. National Centers For Environmental Information, State of The Climate: Global Climate Report For Annual 2019. Available at Https://Www.Ncdc.Noaa.Gov/Sotc/Global/201913. (Accessed On 16 March 2020).

Paek H, Yu J Y, Qian C. (2017). Why Were The 2015/2016 And 1997/1998 Extreme El Niños Different? Geophys Res Lett, 44: 1848-1856.

René D. Garreaud Juan P. Boisier, Roberto Rondanelli, Aldo Montecinos, Hector H. Sepúlveda Daniel Veloso-Aguila (2019) The Central Chile Mega Drought (2010-2018): A Climate Dynamics Perspective. International Journal of Climatology, Royal Meteorological Society

Risbey J S, Lewandowsky S, Langlais C, Monselesan D P, O'Kane T J, Oreskes N. (2014). WellEstimated Global Surface Warming In Climate Projections Selected For ENSO Phase. Nat Clim Change, 4: 835-840

Rosenzweig, C. \& D. Hillel (2008). Climate Variability and The Global Harvest: Impacts Of El Niño And Other Oscillations on Agroecosystems, Oxford University Press New York.

Ropelewski, C. F. \& M. S. Halpert (1996). Quantifying Southern Oscillation-Precipitation Relationships. Journal of Climate 9(5), 1043-1059.

Renganathan Giridharana \& Rohinton Emmanuelb (2018). The Impact of Urban Compactness, Comfort Strategies, And Energy Consumption on Tropical Urban Heat Island Intensity: A Review. Sustainable Cities and Society, 40, 677-687. 
Rajashree Vinod Bothale \& Yashwant B. Katpatal (2014). Response of Rainfall And Vegetation To ENSO Events During 2001-2011 In Upper Wardha Watershed, Maharashtra, India. Journal of Hydrologic Engineering, 19(3).

Salleh, Siti Aekbal And Abd.Latif, Zulkiflee And Wan Mohd, Wan Mohd. Naim And Chan, Andy (2018) Land Covers and Climate Impacts On Land Surface Temperature In Putrajaya, Malaysia Asian Journal Of Environment-Behaviour Studies, 3(10), 1-11

Suhaila, J. \& Yusop, Z. (2018). Trend Analysis and Change Point Detection of Annual and Seasonal Temperature Series in Peninsular Malaysia. Meteorology and Atmospheric Physics, 130, 565581.

Tang, K. H. D. (2019). Climate Change in Malaysia: Trends, Contributors, Impacts, Mitigation and Adaptations. Science of The Total Environment, 650, 1858-1871.

Tangang, F., Juneng, L., Salimun, E., Sei, K. \& Loh, J. (2012). Climate Change and Variability Over Malaysia: Gaps In Science And Research Information. Sains Malaysiana, 41, 1355-1366.

Tavakol, A., Rahmani, V. \& Harrington, J. (2020). Evaluation of Hot Temperature Extremes And Heat Waves In The Mississippi River Basin. Atmospheric Research, 239, 104907

Trenberth, K. E. \& D. P. Stepaniak (2001). Indices Of El Niño Evolution. Journal of Climate, 14(8), 1697-1701.

Turkington, T., Timbal, B., \& Rahmat, R. (2018). The Impact of Global Warming on Sea Surface Temperature Based El Nino Southern Oscillation Monitoring Indices. International Journal of Climatology, 39(2).

Villoria, N. B. (2015). The Role of Variable Trade Policy and Early Warnings in Mitigating The Global Effects Of El Nino Southern Oscillation. I. F. P. A. C. Teleconnections

Yu J, Paek H \& Saltzman (2015). The Early 1990s Change In ENSO-PSA- SAM Relationships and Its Impact on Southern Hemisphere Climate. J Clim, 28: 9393-408

Zulfaqar Sa'adi, Shamsuddin Shahid, Tarmizi Ismail, Eun-Sung Chung, And Xiao-Jun Wang (2017). Distributional Changes in Rainfall and River Flow in Sarawak, Malaysia. Asia-Pac. J. Atmos. Sci., 53(4), 489-500.

Zhang, K., B. Thapa, M. Ross, And D. Gann. (2016). Remote Sensing of Seasonal Changes and Disturbances in Mangrove Forest: A Case Study from South Florida. Ecosphere, 7(6). 